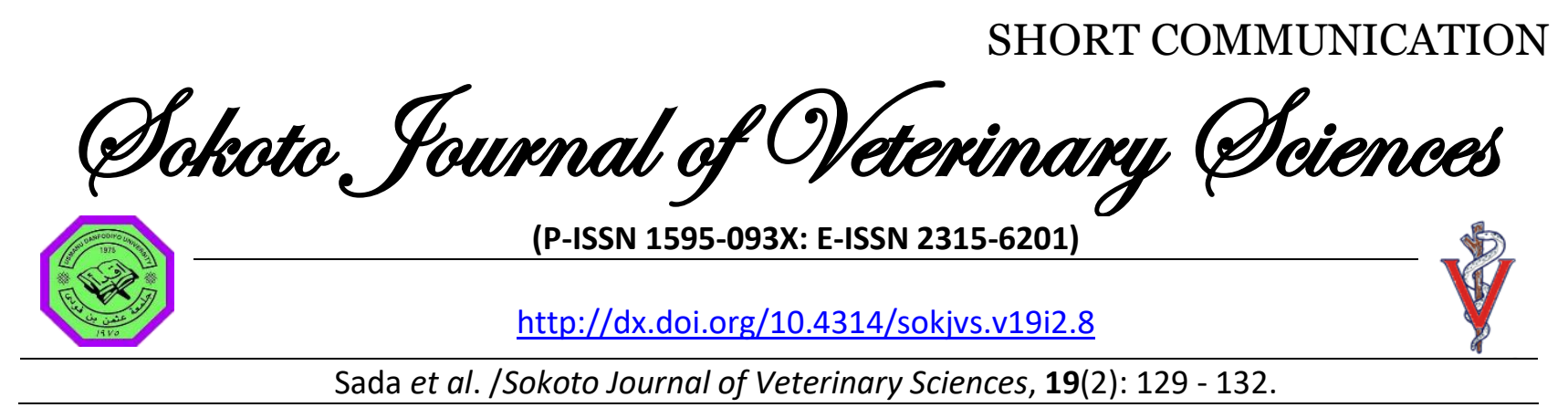

\title{
Serological survey and isolation of Mycoplasma mycoides subspecies mycoides from cattle slaughtered at Katsina state central abattoir, Nigeria
}

\author{
A Sada ${ }^{1}$, FM Tambuwal ${ }^{2}$, GO Egwu ${ }^{3} \mathrm{KH} \mathrm{Ahmad}^{4 *}$, BN Umar $^{4}, \mathrm{AM}$ Ibrahim $^{5}$ \& MS \\ Abdullahi ${ }^{6}$ \\ 1. National Veterinary Research Institute NVRI, Vom, Plateau state, Nigeria \\ 2. Department of Veterinary Microbiology, Usmanu Danfodiyo University, Sokoto, Nigeria \\ 3. Department of Veterinary Microbiology, University of Abuja, Nigeria \\ 4. Department of Veterinary Microbiology, Ahmadu Bello University, Zaria, Nigeria \\ 5. Department of Veterinary Public Health and Preventive Medicine, Usmanu Danfodiyo University, Sokoto, \\ Nigeria \\ 6. Veterinary Council of Nigeria, Abuja, Nigeria
}

*Correspondence: Tel.: + 2348036395435; E-mail: kabirbka@gmail.com

\begin{abstract}
Copyright: (c) 2021
Sada et al. This is an open-access article published under the terms of the Creative Commons Attribution License which permits unrestricted use, distribution, and reproduction in any medium, provided the original author and source are credited.
\end{abstract}

Publication History: Received: 21-10-2020

Revised: 20-02-2021

Accepted: 25-02-2021

\begin{abstract}
A serological survey for the detection of antibodies to Mycoplasma mycoides subspecies mycoides ( $\mathrm{Mmm}$ ) from cattle slaughtered at Katsina Central Abattoir was conducted from March to October 2012 using competitive ELISA (CIRAD) version: P05410/04 antibody detection kit. A total of 300 cattle sera were screened for Mmm antibodies out of which $22(7.3 \%)$ obtained from 15 (68.2\%) cows and $7(31.8 \%)$ bulls were positive. Age distribution indicated that $3(13.6 \%)$ were less than 2 years, 11 $(50 \%)$ were between 2 and 4 years of age, while $8(36.4 \%)$ were above 4 years. The study confirmed the susceptibility of some cattle breeds from all ages and sexes to $\mathrm{Mmm}$. However, middle-aged cows were shown to be more associated with the infections though not statistically significant $(P>0.01)$. Similarly, a total of 130 pneumonic lung tissues were used for isolation and biochemical characterization of Mmm out of which $2(1.5 \%)$ samples one each from adult White Fulani and Red Bororo cows were found to be positive. The study established baseline information on the status of $\mathrm{Mmm}$ infection in Katsina State. Continuous disease surveillance and annual mass vaccination programme using effective vaccines were recommended.
\end{abstract}

Keywords: Abattoir, Cattle, Katsina, Mycoplasma mycoides mycoides, Seroprevalence

\section{Introduction}

Mycoplasma mycoides subspecies mycoides ( $\mathrm{Mmm}$ ) is the causative agent of contagious bovine pleuropneumonia (CBPP), a highly contagious and major trans-boundary respiratory disease of cattle in the world. It is the only bacterial disease listed in list ' $A$ ' of the Office International des Epizooties (OIE) reportable diseases (Ankeli et al., 2017; Francis et al., 2018). The socio-economic impacts of CBPP are 
enormous, resulting in heavy loss of cattle population (Wade et al., 2015). Similarly, CBPP is one of the most important cattle diseases in Nigeria owing to its considerable effects on livestock production and economy through indirect losses by exclusion from participation in international livestock trade (Suleiman et al., 2015; Francis et al., 2018). Despite vaccination campaigns by some states in Nigeria, CBPP outbreaks with morbidity and mortality rates ranging from $25 \%$ to $50 \%$, continue to occur leading to estimated annual economic loss of at least $\$ 2.2$ billion (Aliyu et al., 2000).

Mycoplasma mycoides subspecies mycoides is facultative anaerobe (OIE, 2002). The organism grows well on mycoplasma agar and has unique characteristic fried egg (nipple shaped) appearance under stereomicroscope (Francis et al., 2018). Mycoplasma mycoides can be biochemically identified based on its capacity to ferment glucose, reduce tetrazolium, digest casein, lack of phosphatase activity, as well as inability to hydrolyse arginine. Complement fixation test (CFT) and enzyme linked immunosorbent assay (ELISA) are the commonly recommended serological tests for CBPP diagnosis in most parts of Europe and Africa (OIE, 2002). However, ELISA is reported to be more sensitive than the CFT and has been shown to discriminate antibodies between natural infection and vaccination (Le Goff \& Thiaucourt, 1998). Despite the endemicity of mycoplasma infection in Nigeria, there is paucity of information on the status of CBPP in Katsina state. Therefore, in view of the abundant livestock population in the state, its important geographical location with boundaries to many northern states and Niger Republic, as well as the unrestrained movement of animals within and out of Katsina state, there is urgent need to determine the status of CBPP in the study area.

\section{Materials and Methods}

Study area

Katsina state is located between latitudes $11^{\circ} 08 \mathrm{~N}$ and $13^{\circ} 22 \mathrm{~N}$ and longitude $6^{\circ} 52 \mathrm{E}$ and $920 \mathrm{E}$.

\section{Sample collection}

For serum collection, a systemic random sampling technique was adopted in which for every five slaughtered cattle, one was selected. A total of 300 blood samples $(10 \mathrm{ml})$ comprising of 152 samples from Red Bororo, 101 from White Fulani and 47 from Sokoto Gudali breeds of cattle were aseptically collected using sterile vacutainers at point of slaughter within the period of 10 weeks. The samples were transported using ice pack containers (Coleman coolers) to the National Veterinary
Research Institute (NVRI) Katsina state outstation laboratory, then centrifuged at 1000rpm for 10 minutes to harvest the needed sera. Similarly, a purposive sampling technique was adapted during post-mortem examination of slaughtered cattle for tissue collection. Pathologic lesions suggesting CBPP were observed and recorded. A total of 130 pneumonic lung tissues were collected within the period of 10 weeks and transported to NVRI Vom, Plateau State for isolation and biochemical characterisation of $\mathrm{Mmm}$. Each sample was accompanied with a checklist indicating breed, age, sex, and post mortem report.

\section{Serological analysis}

Competitive enzyme-linked immunosorbent assay (cELISA) kit (CIRAD, P05410/04) based on monoclonal anti-Mmm antibody (Mab 177/5) was employed to detect antibodies to $\mathrm{Mmm}$ from the test sera as described by the manufacturer. Optical densities (ODs) were read using microtitre ELISA plate reader (Multiskan EX ELISA reader) at $450 \mathrm{~nm}$ and cut-off points were calculated to validate the results. All sera with percentage inhibition $(\mathrm{PI})>50 \%$ were considered positive.

Isolation and biochemical characterisation of Mycoplasma mycoides

Isolation of $\mathrm{Mmm}$ was done as described by Thiaucourt et al. (2011). Five serial 10 fold dilutions $\left(10^{-1}\right.$ to $\left.10^{-4}\right)$ of macerated lung tissues were made according to Hayflick \& Robert (1965) using modified Hayflick's broth (2.1g Difco ${ }^{\circledR}$ PPLO broth, 20\% decomplemented horse serum, $10 \%$ fresh yeast extract, $0.2 \%$ glucose, $0.4 \%$ sodium pyruvate, $0.04 \%$ ampicillin, $1 \%$ phenol red, and $70 \mathrm{mls}$ of deionized water). The last dilution $\left(10^{-4}\right)$ was cultured on Hayflick agar plates then incubated at $37^{\circ} \mathrm{C}$ using $5 \%$ carbon dioxide incubator for 5 days. The incubated plates were examined using stereomicroscope (x35) for mycoplasma-like ('fried egg') colonies daily starting from day 3 post incubation. The positive colonies were biochemically characterized using glucose fermentation, tetrazolium salt reduction, arginine hydrolysis, phosphatase, and growth inhibition tests.

\section{Statistical analysis}

Chi-square test was used to determine association between occurrence of antibodies and age, sex or breeds. Fisher's exact test was used to determine the relationship between sero-prevalence and isolation rate. Value of $\mathrm{P}<0.01$ was considered significant. 
Table 1: Distribution of antibodies to Mycoplasma mycoides using c-ELISA by age, sex and breed of cattle slaughtered at Katsina central abattoir, Katsina state, Nigeria

\begin{tabular}{llllll}
\hline Factor & Category & No. Sampled & No. Positive & Positive (\%) & P-value \\
\hline \multirow{2}{*}{ Sex } & Bulls & 112 & 7 & 6.25 & 0.7439 \\
& Cows & 188 & 15 & 7.98 & \\
Age & $\leq 2$ years & 71 & 3 & 4.23 & \\
& $>$ 2 to 4 years & 155 & 11 & 7.1 & 0.3105 \\
& $>4$ years & 74 & 8 & 10.81 & \\
Breed & White Fulani & 101 & 7 & 6.93 & \\
& Red Bororo & 152 & 11 & 7.24 & 0.9408 \\
& Sokoto Gudali & 47 & 4 & 8.51 & \\
\hline
\end{tabular}

$\mathrm{P}>0.01$

\section{Results and Discussion}

Out of the 300 sera sampled, 22 (7.33\%) comprising of $15(68.2 \%)$ cows and $7(31.8 \%)$ bulls had percentage inhibition greater than $50 \%$ which were considered positive (Table 1). The overall seroprevalence recorded using c-ELISA in the present study closely correlates with the $8.75 \%$ reported by Francis et al. (2017), but higher than the $0.29 \%$ reported by Aliyu et al. (2000). Conversely, the established rate was lower than the $30.2 \%, 26.0 \%$ and $56.2 \%$ reported by Suleiman et al. (2015), Billy et al. (2017) and Olorunshola et al. (2020) respectively. The diverging reports over time is an indication of increasing endemicity of CBPP, with gradual spread from north to other parts of the country as similarly noted by OIE (2013).

We hypothesised that the $7.33 \%$ overall seroprevalence recorded might have exaggerated the occurrence of CBPP in the study area since some of the cattle sampled were vaccinated as shown by the record of Ministry of Agriculture and Natural Resources. Nonetheless, being the first documented work on CBPP from the region, it presents baseline information about the status of the disease in the state.

Breed distribution of CBPP carriers showed Red Bororo $11(50 \%)$ to be the most affected breed, White Fulani 7 (31.8\%) were moderately affected, and Sokoto Gudali 4 (18.2\%) had the least occurrence. Similarly, age distribution indicated 3 (13.6\%) were less than 2 years, 11 (50\%) were between 2 and 4 years of age, while $8(36.4 \%)$ were above 4 years (Table 1). Therefore, the percentage proportional distribution of CBPP carriers showed Red Bororo, adult cows had more association with the disease (Table 1). The higher occurrence rate in adult cows poses serious threat to cattle production in the country because the older cows are normally the parent stock in the herd compared to the bulls that are usually disposed to meet the family needs. These infected cows in the herd could be a point

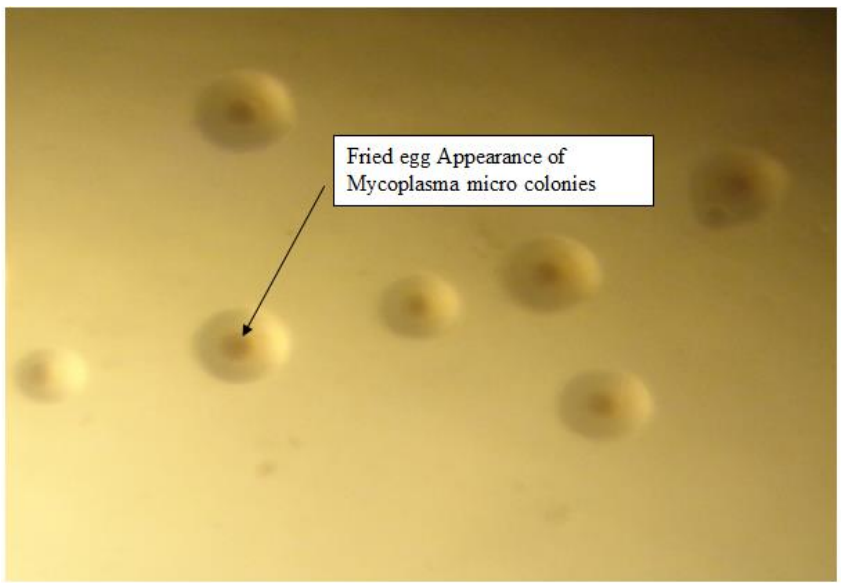

Plate I: Mycoplasma mycoides subspecies mycoides isolated from lung tissue of pneumonic cattle slaughtered at Katsina central abattoir, Katsina state, Nigeria

source of infection to naive animals thereby maintaining the endemicity of the disease. This concurs with what was documented by Billy et al. (2017), Francis et al. (2017) and Olorunshola et al. (2020) who independently reported $27.1 \%$ versus $21.9 \%, 8.93 \%$ versus $8.33 \%$ and $55.9 \%$ versus $0.3 \%$ for cows and bulls respectively. The increased serodetection rate observed in middle aged cattle agrees with the finding of Suleiman et al. (2015), but differs with that of Billy et al. (2017) who reported a highest prevalence of $30 \%$ in cattle of over 6 years.

Interestingly, only $2(1.5 \%)$ out of the 130 pneumonic lungs, precisely one each from adult White Fulani and Red Bororo cows were found to be positive of the organisms. The two isolates had a characteristic fried egg appearance under stereomicroscope (Plate I).

They were incapable of hydrolysing arginine, had no phosphatase activity, but fermented glucose, and tetrazolium. Likewise, their growth was inhibited by specific antiserum to Mycoplasma mycoides subspecies mycoides (Table 2 ). The $1.5 \%$ isolation rate recorded was slightly lower than $4.0 \%$ reported 
Table 2: Biochemical characterisation of Mycoplasma mycoides isolated from lung tissues of cattle slaughtered at Katsina central abattoir, Katsina state, Nigeria

\begin{tabular}{llllll}
\hline Isolates & $\begin{array}{l}\text { Glucose } \\
\text { fermentation }\end{array}$ & $\begin{array}{l}\text { Arginine } \\
\text { hydrolysis }\end{array}$ & $\begin{array}{l}\text { Tetrazolium } \\
\text { reduction }\end{array}$ & $\begin{array}{l}\text { Phosphatase } \\
\text { activity }\end{array}$ & $\begin{array}{l}\text { Growth } \\
\text { inhibition }\end{array}$ \\
\hline $1^{\text {st }}$ isolate & + & - & + & - & + \\
$2^{\text {nd }}$ isolate & + & - & + & - & + \\
\hline
\end{tabular}

by Ikpa et al. (2020) respectively. Although the isolation rate was low, the study confirmed the presence of CBPP in Katsina State. It has equally established preliminary data on the prevalence and some risk factors associated with CBPP in the state. Continuous surveillance and quarantine of infected cattle as well as re-enforcement of eradication strategy through compulsory annual mass vaccinations are recommended.

\section{Acknowledgement}

Authors appreciate Katsina State Ministry of Agriculture and Natural Resources, and the management of NVRI Vom, Nigeria.

\section{Conflicts of Interest}

The authors declare no conflict of interest.

\section{References}

Aliyu MM, Obi TU \& Egwu GO (2000). Prevalence of contagious bovine pleuropneumonia in Northern Nigeria. Preventive Veterinary Medicine, 47(4): 263-269.

Ankeli PI, Raji MA, Kazeem HM, Tambuwal FM, Francis MI, Ikpa LT, Fagbamila IO, Luka PD \& Nwankpa ND (2017). Seroprevalence of contagious bovine pleuropneumonia in Plateau state, North-central Nigeria. Bulletin of Animal Health and Production in Africa, 65(2): 357-366.

Billy IL, Balami AG, Sackey AKB, Tekdek LB, Sa'idu SNA \& Okaiyeto SO (2017). Seroprevalence of contagious bovine pleuropneumonia in three senatorial district of Kaduna state, Nigeria using latex agglutination test. World Veterinary Journal, 7(2): 65-73.

Francis MI, Ankeli PI, Ikpa LT, Maichibi MS \& Fagbamila 10 (2017). First report of contagious bovine pleuropneumonia in a herd of Friesian cattle at Birnin-kudu, Jigawa state, Nigeria. Vom Journal of Veterinary Science, 12: 41-45.

Francis MI, Oragwa AO, Ankali PI, Liba JW, Ejeh EF, Raji MA, Ameh JA \& Egwu GO (2018). Prevalence of contagious bovine pleuropneumonia based on gross lesions in cattle slaughtered in Adamawa State, Nigeria. Sokoto Journal of Veterinary Sciences, 16(3): 31-37.
Hayflick L \& Robert MC (1965). Mycoplasma media, Microbiology and Molecular Biology Reviews. 29(2): 185-221.

Ikpa LT, Bwala DG, Ankeli PI, Kaikabo AA, Maichibi MS, Maurina IA, Abenga JN, Nwankpa ND \& Adah MI (2020). Isolation and molecular characterization of Mycoplasma mycoides subspecie mycoides in 3 agro ecological zones of Nasarawa state, Nigeria. Open Journal of Veterinary Medicine, 10(02):15.

Le Goff C \& Thiaucourt F (1998). A competitive ELISA for the specific diagnosis of contagious bovine pleuropneumonia (CBPP). Veterinary Microbiology, 60(2-4): 179-191.

OIE (2002). Contagious Bovine Pleuropneumonia classified as an OIE List A disease A060: 1-4.

OIE (2013). Office International Des Epizooties Manual of diagnostic tests and vaccines for terrestrial animals. OIE, Paris. https://www.oie.int/doc/ged/D12009.

Olorunshola ID, Daodu BO, Ajiboye B, Folaranmi EB, Nicholas RAJ, Adegboye DS \& Peters AR (2020). Seroprevalence of contagious bovine pleuropneumonia and contagious caprine pleuropneumonia in the MiddleBelt of Nigeria. African Journal of Microbiology Research, 14(1): 25-31.

Suleiman A, Bello M, Dzikwi AA, Talba AM, Grema HA \& Geidam YA (2015). Serological prevalence of contagious bovine pleuropneumonia in agro-pastoral areas of Nigeria. Tropical Animal Health and Production, 47(6): 1033-1042.

Thiaucourt F, Manso-Silvan L, Salah W, Barbe V, Vacherie B, Jacob D, Breton M, Dupuy V, Lomenech AM, Blanchard A \& SirandPugnet P (2011). Mycoplasma mycoides, from "mycoides small colony" to "capri". A microevolutionary perspective. BMC Genomics, doi.10.1186/1471-2164-12-114.

Wade A, Yaya A, El-Yuguda AD, Unger $H$, Nafarnda WD, Ikechukwu ES \& Egwu GO (2015). The prevalence of contagious bovine pleuropneumonia in Cameroun: A case study of Garoua central abattoir. Cameroun Journal of Veterinary Medicine and Research, 2(4): 1029-1034. 